\title{
Associated Persons Identifier
}

National Cancer Institute

\section{Source}

National Cancer Institute. Associated Persons Identifier. NCI Thesaurus. Code C117707.

A character or string that identifies and represents a single associated person, a group of associated persons, or a pool of associated persons. 